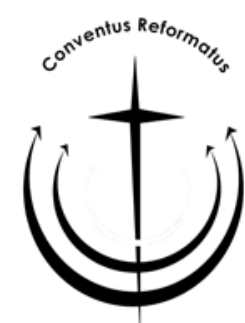

\title{
Calvin on the sacraments and church unity
}

\author{
D.J. Smit
}

Department of Systematic Theology

University of Stellenbosch

STELLENBOSCH

E-mail: djs1@sun.ac.za

\begin{abstract}
Calvin on the sacraments and church unity

Calvin's ecumenical passion has often been documented by scholars (section 1). This article argues that these practical endeavours were based on Calvin's ecclesiological conviction that there is only one church (section 2), based on the communio of believers with Christ and with one another (section 3), in which the sacraments, particularly the Lord's Supper, play a crucial role as the bonds of communio (section 4). For Calvin, this concretely implied that believers who participate in the celebration of the Supper should also love one another, as quotations from the 1559 "Institutes" powerfully demonstrate (section 5). Given the ambiguous legacy of Calvin in South Africa, these views of Calvin present a continuous challenge to South African churches in his tradition (section 6).
\end{abstract}

\section{Opsomming}

\section{Calvyn oor die sakramente en die eenheid van die kerk}

Calvyn se ekumeniese gees en toewyding is al dikwels deur geleerdes beskryf (afdeling 1). Hierdie artikel argumenteer dat die praktiese strewes van Calvyn gemotiveer is deur sy ekklesiologiese oortuiging dat daar slegs een kerk is (afdeling 2), wat berus op die communio van gelowiges met Christus en met mekaar (afdeling 3), waarin die sakramente, veral die Nagmaal, 'n sleutelrol vervul as die bande van gemeenskap (afdeling 4). Vir Calvyn het dit konkreet ingehou dat gelowiges wat aan die Nagmaal deel het ook mekaar behoort lief te hê, soos wat aanhalings uit die 1559-"Institusie" op kragtige wyse toon (afdeling 5). In die lig van die ambivalente erfenis van Calvyn in Suid- 
Afrika bied hierdie sienings van Calvyn nog steeds 'n uitdaging aan Suid-Afrikaanse kerke wat in sy tradisie staan (afdeling 6).

\section{1. "Always have I protested how eager I was for unity": ecumenical passion}

In their small study offered to all member churches for study and discussion during the 500th anniversary of Calvin's birth, called The legacy of John Calvin (WARC, 2008), the very first challenge that the World Alliance of Reformed Churches raises is "making manifest the gift of communion". They are of course referring to Calvin's strong views on "the unity of the church". They contrast this with "today's divisions" and invite member churches today to reflect on "some deeper reasons for the trend towards fragmentation" and to ask themselves "how the gift of communion can be made more manifest". This central place for Calvin's views on the importance of the unity of the church is not at all surprising. It indeed reflects his strong and passionate convictions regarding the church's unity - it is a gift that should also be made manifest, visible.

Calvin's own many and varied practical endeavours to follow this call during his own day are equally well-known. 1 Somewhat anachronistically - since the contemporary use of the term in a world marked by Protestant denominationalism is not really applicable to the circumstances of his own time - these practical attempts are often described as Calvin's ecumenicity. Already in 1959 Nijenhuis focused on Calvin's letters as one way of serving the church's unity and attempting to make the communion between the growing number of Protestant congregations real and visible. Dedicating his study to the World Council of Churches (1959), he argued that Calvin's correspondence - with theologians and church leaders, with sovereigns and nobility, and with many refugee churches - may indeed be described as ecumenical in the modern sense of "the consciousness of and desire for Christian unity".

1 Already in 1539, in his well-known letter to Sadolet on behalf of the congregation in Geneva, he could protest (in the form of a prayer) how passionate he had always been about the unity of the church - a claim that he would continue to fulfil over the decades to follow.

With whom the blame rests it is for thee, O Lord, to decide. Always, both by word and deed, have I protested how eager I was for unity. Mine, however, was a unity of the Church, which should begin with Thee and end with Thee. For as oft as Thou didst recommend to us peace and concord, thou, at the same time, didst show that Thou wert the only bond for preserving it. (Calvin, 1958, 1:3-69.) 
Since then, many scholars have demonstrated different aspects of Calvin's ecumenical passion for the visible unity of the church. In his helpful series of fourteen collections of key essays on Calvin and Calvinism, the scholar from Calvin Theological Seminary, Richard Gamble, republished several early essays on Calvin and ecumenicity (volume 10 on ecclesiology and the sacraments, Gamble, 1992, with essays by well-known figures like McNeill, Kromminga and Stanford Reid). The widely respected reformed theologian in the ecumenical movement, Lukas Vischer, made an enormous contribution over decades and in many different speeches and papers (see only his collection of moving quotations from Calvin with his own introductory essay in Vischer, 2000, as well as Vischer, 2002). Another influential figure in ecumenical circles and former President of the WARC, the Reformation historian from Princeton, Jane Dempsey Douglass, published similar contributions (e.g. Douglass, 2004; 2005). The Dutch ecumenist, Karel Blei, and the Swiss Reformed and ecumenical church leader, Gottfried Locher, both reflected on notions of community, catholicity and visible unity in Calvin and the reformed tradition in recent publications (Blei, 2005; Locher, 2004). Influential doctrinal theologians like Berkouwer and more recently Bram van de Beek and Martien Brinkman in the Netherlands and Alistair Heron in Germany all drew on Calvin in important discussions of the unity and catholicity of the church, almost all of them in contexts of ecumenical dialogues or discussions (Berkouwer, 1970; Van de Beek, 2002; Brinkman, 2007; 2006; Heron, 2002).

Just during the last year, as part of the celebration of 500 years of Calvin's legacy, a number of important studies have become available on Calvin's views on the unity of the church. Another ecumenical authority and member of several ecumenical dialogues, the Dutch expert in reformed polity, Leo Koffeman, published an essay on the ecumenical factor in Calvin (Koffeman, 2009). Germanspeaking Calvin scholars like Plasger (2008a), Beintker (2009) and Opitz (2009a) made insightful contributions, and so too the Waldensian theologian Emidio Campi (2007), the Roman-Catholic scholar Eva-Maria Faber (2009) and the Lutheran ecumenist from Strasburg, André Birmelé (2009) - all of them directly on Calvin's commitment to the unity of the church.

In South Africa, J.J.F. (Jaap) Durand discussed Calvin's strong views concerning visible church unity as early as 1961 in his doctoral dissertation (Durand, 1961) and in 1964 wrote an authoritative and challenging essay on true ecumenicity according to the reformed tradition in the controversial and prophetic volume of essays 
called Die ekumene (Durand, 1964a; cf. also Durand, 1964b). A decade later, Duvenage would publish an annotated bibliography of a long list of contributions on "Calvyn en die ekumeniese roeping van die kerk" (Duvenage, 1977). In his influential albeit controversial writings on the call to visible church unity, the South African systematic theologian W.D. (Willie) Jonker would depend heavily on Calvin's views (cf. Jonker, 1962; 1965).

\section{Societas cum Christo: only one church}

In Calvin, these so-called ecumenical convictions and all these practical attempts to serve the visible unity of the church are not merely practical, pragmatic or even political activities, but are themselves ultimately based on deep ecclesiological convictions. 2 Calvin calls, strives and works for visible unity because he believes that the church of Jesus Christ is one. There is only one church. The church cannot be divided or fragmented. The unity, or the communion, of the church is - in the words of WARC (2008) - a gift, and therefore a given; a reality; the point of departure. The unity is not something that must be achieved or established, but it is a gift, a reality received from the triune God (for the correspondence between Calvin's trinitarian vision and the visibility of grace in his ecclesiological thought, cf. Butin, 1995; for his ecclesiology, cf. Busch, 1997 and Schmidt, 1972 with annotated sources from Calvin himself; for discussions, cf. George, 1990 and Vischer, 2002, together with the other essays; for a helpful overview, cf. Plasger, 2008a). The unity is not made, but rather made manifest - and the difference in ecclesiology is enormous.

Perhaps the insightful observations of Birmelé - as renowned ecumenist, but also as Lutheran theologian - could serve to summarise and underline these ecclesiological convictions underlying Calvin's so-called ecumenical endeavours.

Calvin concerned himself more than the other Reformers with the question of the unity of the church. He never grew tired of emphasizing his concern for 'unity and unanimity' ... In his correspondence with Cranmer he described the disunity of the church as amongst the greatest evils of our century and showed the same suffering as a result of the separation

2 For example: "Calvins Haltung ... beruhte nicht nur auf Motiven der höheren europäischen Politik, zu der er freilich das Seine beitrug. Bestimmend für sie war vielmehr seine Sicht der Einheit der Kirche." (Van 't Spijker, 2001:199-200.) 
between churches that is also the motivation behind ecumenicity today. (Birmelé, 2009:103-104; translation and paraphrase - DJS.)

This concern for the unity, argues Birmelé, is the result of Calvin's particular understanding of the church. Calvin knew the Confessio Augustana and its famous Article 7 on the unity of the church (residing in proper preaching and administration of the sacraments) and of course agreed with this deeply protestant position, yet he used different terminology and put his own emphases to guard against particular misunderstandings. For example, he added the words "and heard" - the gospel should be purely preached "and heard" (for a discussion, cf. Smit, 2009) ${ }^{3}$ - and he preferred the term communion (communio, also koinonia, with Christ and also with one another) instead of congregation (congregatio, of the Confessio Augustana). Especially in his commentary on the epistles to the Corinthians - and thus also in his understanding of the Lord's Supper and the sacraments - this is of crucial importance.

The communio with Christ and, therefore, with one another, is at the heart of being the church for Calvin (developing communio-ecclesiologies or koinonia-ecclesiologies has of course become the most promising ecumenical ecclesiological approach in recent years (cf. Best \& Gassmann, 1994; Birmelé, 2003). For a detailed analysis of contemporary ecumenical documents and studies, cf. Fuchs, 2008). This is precisely the reason why there can be only one church, because Christ is one and cannot be divided or torn apart. This is the reason why all schism and heresy, all separation and alienation, all fragmentation and division within the visible body of Christ is so terrible and so completely unacceptable. This is why such divisions

Opitz, 2009a:225:

Die Kirche 'reformieren' bedeutete für Calvin, wie für anderen Reformatoren, keine mit bestimmten Maßnahmen zu erreichend Selbtsreinigung einer Institution. Vielmehr ging es zunächst um einen Akt des 'Hörens', beginnend mit einer 'Lernbereitschaft' im Blick auf den biblisch bezeugten Willem Gottes für seine Kirche. Ein Hören allerdings, das in Akte der 'Reinigung' und 'Wiederherstellung' mündete.

Ein letzter Punkt ist für Calvin wichtig. Die Einheit der Kirche verlangt sowohl die Übereinstimmung in der Predigt der Evangeliums wie auch ein einträchtiges gemeinsames Leben innerhalb der Gemeinde, wobei jeder seine Charismen einbringt und seine Gaben de Allgemeinheit zur Verfügung stellt. Calvin betont dies nicht nur gelegentlich ... Ohne das Lebenszeugnis aller Gemeindeglieder kann es keine Einheit der Kirche geben. (Birmelé, 2009:118.) 
should in no way be described in terms that make them normal and innocent, but should be resisted and overcome, if at all possible which is why he was willing to cross ten seas in an attempt to achieve this (Calvin, 1980:130-133). 4

This means, of course, that Calvin's view of the unity of the church is in conflict with many of the assumptions about the church that have become commonly accepted and practised in Protestantism, as Birmelé (2009:104-108) shows. Protestant ecclesiology today suffers from deep-seated ecclesiological deficiencies, very often unnoticed and unknown, and they become glaringly obvious and deeply disturbing when contrasted with Calvin's understanding of the church (Birmelé, 2009:106). He particularly points to three fundamental implications of Calvin's ecclesiology.

Firstly, for Calvin, the church is the object of faith, the object of the creed and the church's confession - and not merely the result of human decisions to come together, to worship with others or to form congregations with like-minded people. The church has a divine dimension, it results from the work of the triune God - and is therefore one (Birmelé, 2009:105-106). Secondly, the church is the mother of all believers, according to Calvin's opening argument in Book 4 of the 1559 Institutes - which again means that there can be only one church, not many. The church is not the consequence of human activity, but the source of our communio, of believers' faith and belonging (Birmelé, 2009:106). Thirdly, it is not for us to decide whether we will belong to the church, or not, or to which church we wish to belong to, or not, or - even worse and almost beyond imagination - whether we will allow believers in the church or exclude believers from the church. Outside of the church there is no salva-

$4 \quad$ From his often quoted letter to Thomas Cranmer, Archbishop of Canterbury and Primate of England in April 1552, on the need for an assembly to further more visible unity between the reformed churches.

This other thing also is to be ranked among the chief evils of our time, viz. that the Churches are so divided, that human fellowship is scarcely now in any repute amongst us, far less that Christian intercourse which all make a profession of, but few sincerely practice. If men of learning conduct themselves with more reserve than is seemly, the very heaviest blame attaches to the leaders themselves, who, either engrossed in their own sinful pursuits, are indifferent to the safety and entire piety of the Church, or who, individually satisfied with their own private peace, have no regard for others. Thus it is that the members of the Church being severed, the body lies bleeding. So much does this concern me, that, could I be of any service, I would not grudge to cross even ten seas, if need were, on account of it. (Calvin, 1980:132-133.) 
tion, Calvin agrees with the tradition, and that means the one church, the only church (Birmelé, 2009:106). It is obvious how these convictions of Calvin contrast with many popular ecclesiological notions in contemporary Protestantism, including many reformed traditions, also in South Africa. $\mathbf{5}$

In this regard, Calvin's distinction between the invisible and visible church fulfils an important function, but not in the way of two widespread and popular misunderstandings (for a helpful analysis, cf. Locher, 2004).

Firstly, for Calvin, the unity of the visible church does not consist in uniformity - and he is remarkably open and accommodating in his views of the legitimate and valuable role of complexity, locality, contextuality, custom, particular needs, and diversity in the one body of Christ. This is characteristic of Calvin and abundantly clear in the 1559 Institutes. The diversity involves interpretation, formulation, confessions, order, the ministries, the forms of local worship, and much more - in short, a remarkable freedom and a complete lack of uniformity.

Secondly, the tragic fragmentations, divisions and separations in the visible church - within congregations and communities, in regions and areas, but also more universally - should be seen and discerned for what they are and should be resisted with every means possible, including his so-called ecumenical spirit of accommodation and tolerance, of respect and openness, of willingness to surrender, agree, accept different, even inferior formulations and practices. His life and his works provide rich examples of this kind of attitude and actions, in the service of making the unity of the church more manifest - in order to be able to witness to the gospel with some credibility and integrity. It is not possible to hide behind the invisible church as the true church - also the truly one church - thereby justifying the divisions, the schisms, the heresies and the lack of love and fellowship of the visible church. The confession that only God knows who belong to the church - the invisible church - serves

5 Of particular interest is, therefore, the Leuenberg process between European protestant churches, in which a remarkable consensus was reached on protestant ecclesiology, in which Calvin's views played an important role, cf. the Leuenberg documents 1 (1995). The same document and its ecclesiology is now discussed on a worldwide level in the joint commission between the Lutheran World Federation (LWF) and the WARC, with a view to fuller communion between these churches worldwide and a fuller understanding of protestant ecclesiology, including the deficiencies in the tradition. 
rather as reminder and call that the visible church should long, pray and work to manifest the unity (cf. Plasger, 2008a). 6

\section{Communio cum Christo: one with Christ}

For Calvin, the church is one because Christ is one - and the church is one with Christ. His ecclesiological views form an integral part of his Christological views - and central in his views about Christ is the so-called mystical union of believers with Christ, the often discussed unio mystica cum Christo at the heart of his life and work. Believers have fellowship with Christ, they share in Christ, they are united with Christ, they are one with Christ - and for Calvin this is the heart of the Christian faith and life and also the heart of the church. In fact, believers belong to one another because they belong to Christ - and not the other way round. They are one with one another, which means the church is one, not because they accept one another or unite themselves with one another - or already belong to one another for whatever natural, biological, cultural or political reason but because they are one with Christ and belong to Christ, because Christ has engrafted them into Himself, because Christ dwells in them and they in Christ, because they partake of Christ, share in Christ, have communion with Christ. Because all of this is true about them, they are also one with one another - in a spiritual koinonia.

In commenting on 1 Corinthians 10:16, Calvin explains:

Paul says, that the cup which has been blessed in this manner is koinonian - the communion of the blood of the Lord. It is asked, in what sense? It is true, that believers are united together by Christ's blood, so as to become one body. It is also true, that a unity of this kind is with propriety termed koinonia (communion). I make the same acknowledgement as to the bread, observing what Paul immediately adds, as it were, by way of explanation - that we all become one body, because we are together partakers of the same bread. But whence, I pray you, comes that koinonia between us, but from this, that we are

$6 \quad$ Plasger, 2008a:367, 369:

De zichtbaarheid heeft bij Calvijn maar voor een klein deel de opgave om ook de aanwezigheid van niet-uitverkorenen te thematiseren. Het zwaartepunt van de theologische behandeling bij Calvijn ligt er veel meer op, dat zij de vorm zal krijgen die overeenkomt met die Evangelie van Jezus Christus, om te kunnen beantwoorden aan de uitverkiezing tot de dienst ... De zichtbare kerk heeft als opgave te lijken op wat geloofd wordt - en daartoe behoort wezenlijk ook de eenheid van de christenen. 
united to Christ in such a way that we are flesh of his flesh, and bone of his bones (Ephesians 5:30)? For we must first of all be incorporated (so to speak) into Christ, that we may be united to each other. Paul is not disputing at present merely in reference to a mutual fellowship among people, but as to the spiritual union between Christ and believers. (Calvin, 1848; slightly abbreviated; italics - DJS.)

We must first of all be incorporated into Christ, so to speak, that we may be united to each other. This is where the communio within the church comes from, the fellowship and belonging, the mutual service and love, the visible unity, namely from the church being united to Christ. Much of Calvin's theology is about this incorporation of believers into Christ.

Again, scholarship is divided about the precise role of these convictions in Calvin's overall theology (whether it is the central organising principle, as some claim, while others deny that his theology has any single organising principle); about the precise nature of this unity in Calvin's own mind (whether it is mystical or not, and what mystical would mean with regard to Calvin); about the precise way to understand the effects and consequences in the lives of believers of this unity (how exactly to understand the so-called double grace of which Calvin speaks as a result of this participation in Christ); about the best way to see the role of the believers in receiving this fellowship with Christ (whether they are merely passive recipients, or also active participants; how to understand faith, if faith is the proper way of receiving this union with Christ; how to understand gratitude, if gratitude is indeed an adequate way of describing the human response; how to understand the Christian life, if the Christian life is indeed an integral part of this participation in Christ) - all these questions of interpretation and reception have been central to Calvin scholarship over centuries, and continued to be central over the last decades, until today.

A few well-known examples can again suffice as reminders of these scholarly debates. The Roman Catholic theologian Dennis Tamburello made an important and often discussed contribution considering the question whether and in which way, if at all, Calvin's views of believers' union with Christ was influenced by the mysticism of Bernard of Clairvaux (Tamburello, 1994). The respected reformation historian Brian Gerrish wrote a ground-breaking and extremely influential study on what he called Calvin's eucharistic theology, called Grace and gratitude, in which he carefully documented and described the nature of believers' participation in Christ, their sacra- 
mental life and Christ's mystical presence (Gerrish, 1993). The renowned Episcopal reformation scholar Randall Zachman recently published a brief and lucid overview of the structure in Calvin's thought which he describes as "communion cum Christo" (Zachman, 2008). In a major monograph, the authoritative Calvin scholar Charles Partee (2008) analyses the theology of John Calvin with the claim that "union with Christ" can indeed be taken as the integrating idea of the whole of the Institutes, a claim that he defends against many divergent voices in the USA. In South Africa, Johan Retief (1984) wrote a doctoral dissertation on the relationship between mortificatio and vivificatio in Calvin in which the unio cum Christo plays a key role in his interpretation.

Perhaps some recent work by the Calvin scholar Todd Billings who received the Templeton Prize for Theological Promise for his doctoral dissertation on Calvin - may serve as instructive illustration. In his study called Calvin, participation, and the gift: the activity of believers in union with Christ, Billings (2007) engages the many contemporary theologians who explore the notions of gift, exchange and participation to describe the relationship between God and human activity and who, in this process, often uses Calvin as a negative foil, critiquing his "inadequate theology of human reciprocity". In a careful study, Billings rejects this kind of criticism by following the theme of "participation in Christ" as it developed from Calvin's earliest work in 1536 to his final treatises in 1561. He claims that Calvin in fact affirmed a differentiated notion of union between God and humanity in both creation and redemption, and developed a wide-ranging and emphatic view of participation in prayer and the sacraments, as well as in the law, church and society. In short, according to Billings, Calvin had a strong sense of the human agency of believers as participants in Christ by the Spirit, and his "theology of participation understands believers as having an active role in the ascetic struggle of prayer, in sharing love within the church and to the neighbour, and in involvement in ecclesial and societal spheres". Summarising his own discussion of Calvin's language of "participation in Christ", Billings can claim that "Calvin not only extends the notion of participation to a wide variety of doctrinal loci; he uses the term to designate a rich communion, or koinonia, which applies to both the Trinitarian adoption of humanity and the rich fellowship of the church" (Billings, 2007; cf. also 2009a; 2009b).

Taken these brief comments together, the thrust is clear. Calvin's ecumenical spirit and practical strivings are motivated by his 
ecclesiological views, which in turn are determined by his central Christological conviction (according to some at least, even his most central conviction), namely that believers are one with Christ (and therefore one with one another), that they truly and really participate in Christ, that they share some mystical fellowship with Christ. The best way to understand his views on this real participation is complex and controversial, but three aspects at least seem clear: firstly, this participation (or union) is rich, varied and complex (it is trinitarian in character; it takes place in the Spirit; it has a bearing on almost all doctrinal loci); secondly, this participation involves human activity, agency, involvement, response, one may even say life and ethics (for example, the union with Christ through the Spirit also manifests in visible and everyday unity with others); and thirdly, according to Calvin the sacraments play a crucial role in this rich and reciprocal participation (the life of participation in Christ is a life of grace and gratitude in which the mystical presence of Christ in the sacraments is fundamental). In short, his ecumenical spirit flows from his ecclesiological views, which are based on his Christological convictions, in which his understanding of the sacraments is central - so that it is time to turn finally to his sacramental theology.

\section{Carifatis vinculum: the sacrament as bond of charity}

However, what precisely was Calvin's view of the sacraments - and where do we find this? Several scholars have recently shown that Calvin did not in fact from the beginning already have a comprehensive and fully developed view of the sacraments (see particularly the instructive summary in Janse, 2008a and the careful historical account in Janse, 2008b, but also Davis, 1995, which Janse describes as an "epoch-making dissertation"; cf. also Davis, 2008). Some people regard Calvin's early account of the sacraments in the Consensus Tigurinus, the agreement concluded with the preachers of Zurich in 1549, as the most representative expression of his sacramental views. Others regard his later account in the 1559 Institutes, published five years before his death, as his authoritative doctrinal formulation of his own view. Janse disagrees, and convincingly demonstrates that Calvin could express himself in many complex and diverse ways regarding the sacraments, depending on his discussion partners and readers at particular points in time (Janse, 2008a:387). ${ }^{7}$

7 In what follows, Calvin's view of baptism is not treated separately, but it is implied in his understanding of the sacraments. Janse (2008a:391) says 
Such an interpretation, of course, fits very well with Calvin's explicit understanding of doctrine and teaching, with his rhetorical theology and his awareness of audience and historical context, and in fact with his ecumenical passion and concern, namely to find agreement, consensus, harmony, visible unity (for helpful recent introductions to Calvin's life and work, including his humanist and rhetorical background, training and approach, cf. Busch, 2007; De Gruchy, 2009; Huizing, 2009; Link, 2009; Opitz, 2009b; Plasger, 2008b; Strohm, 2009; specifically for the rhetorical and contextual nature of his work, cf. Jones, 1995; Compier, 2001; Baard, forthcoming). This historical account of his changing expressions and emphases therefore dramatically illustrates Calvin's commitment to the communion and visible unity of the church, because it shows that, in formulating his view of the sacraments over many years, in diverse contexts and in conversation - sometimes debate, even conflict and division - he was more than willing to accommodate, to make compromises, to accept and support formulations that would not have been his own choice, because he was convinced that reaching agreements in formulation concerning the sacraments should also visibly manifest the gift of unity of the church (cf. also Tylenda, 1981). In short, even his formal participation in the many ecumenical discussions on the sacraments within the deeply divided protestant movement was intended to serve the material participation of the one church in fellowship with Christ and with one another.

"Calvijns visie op de doop is een verbijzondering van zijn sacramentsopvatting" and he explains Calvin's baptismal views in much the same way as he describes the eucharistic theology, namely as different emphases depending on changing historical fronts and discussion partners, although on the whole he regards the baptismal views as "zwingliaanser" than the eucharistic views (Janse, 2008a:394). For Calvin's views on baptism, see Van Genderen (1983), Riggs (2002), and also Spierling (2005) who explicitly claims that her study shows that baptism played an important role in defining the understanding of life in community:

In reducing the number of sacraments from seven to two, protestant reformers including John Calvin dramatically altered the relationship of individual Christians to the institution of the church and changed the way that people understood their individual relationships to God. As a result, the two remaining sacraments of baptism and communion became increasingly important as instruments for defining and unifying the Christian community. To date, most works that examine the dynamics of community definition during the Reformation have focused on the Lord's Supper ... rather that on baptism. This study has demonstrated the need to view infant baptism, the 'other' sacrament, as a fundamental part of the definition and development of Reformed communities. (Spierling, 2005:219; italics - DJS.) 
Of course, there were boundaries that even Calvin was not willing to cross; there were formulations that he could not accept and agree to (and he often expressed that in very harsh terms); there were views of the sacrament (both baptism and the Lord's Supper) that he could not accommodate; and in that sense it is certainly possible to speak about Calvin's views on the sacrament, which Janse (2008b) calls Calvin's gradually formed, own, mature eucharistic theology - it was an open and flexible view, but within definite boundaries.

According to Janse's instructive and well-documented account (with primary and secondary sources, cf. Janse, 2008b for detail), it is helpful to distinguish at least three phases in Calvin's way of seeing and describing the sacraments.

He calls the first phase between 1536 and 1537 a period of Zwinglianising. In several sources from that time, Calvin's formulations come close to the positions of the Zurich theologians, emphasising for example the commemorative and ecclesiologicalethical aspects of the Lord's Supper.

In a second phase, between 1537 and 1548, Calvin sees the possibility that consensus with the Lutherans may become possible, and he therefore - in a whole range of publications, including his commentary on 1 Corinthians (from 1546) - attempts to accentuate the gift character of the Supper and the reality of the presence of Christ and of the unity with Christ and he underplays the commemorative and ecclesiological-ethical aspects. He now stresses that the participation is not only with Christ's benefits, but with Christ himself, that the remembrance should not be taken as merely noetic, that the sign (the real eating and drinking of real bread and wine) should not be separated from the matter signified (spiritual salvation), that the sacramental eating and drinking should not be emptied and made meaningless (just "bare and empty signs"), that the sacrament has an instrumental character, in that something really and truly happens - in that believers are engrafted, united, incorporated, they participate, they obtain Christ himself, Christ dwells in them, et cetera. Of course, Calvin still retains the central concerns of his earlier views, but his ecumenical intention and strategy is also very clear, in that he attempts to find expressions and emphases that would also reassure the Lutheran theologians from the German north and he attempts to avoid any explicit confrontation with Lutheran positions. The earlier quote from 1 Corinthians - we must first of all be incorporated into Christ, so to speak, that we may be united to each other - comes from this phase. 
When it becomes clear, after 1549, that in spite of all these attempts the Lutherans were not willing to join the agreement and accept the Consensus Tigurinus, Calvin seems to shift his focus once again, in a third phase. During the 1550s, therefore, he still retains his earlier positions, but now once again strengthens the emphasis on the role of the Spirit and also the ecclesiological-ethical aspects of the Lord's Supper. 8 In other words, having stressed the real unity with Christ during the 1540s (with a view to the Lutherans) he now once again stresses the visible unity with one another during the 1550s (with a view to retain and strengthen the consensus which he already found with Zurich). Many of the well-known and moving quotes on the visible unity of the church and on the importance of mutual love within the church - incorporated into Christ, believers should practise the communion which the Supper as bond of love made real between them - accordingly come from this period, including Calvin's (by this time very extensive) discussions of the sacraments in the 1559 Institutes. 9

\section{5. "No one can hurt the brethren": on the Lord's Supper and the Christian life}

Thinking about the importance of Calvin's understanding of the sacraments for his views on the unity of the church, it may be instructive to consider some of his expressions on this "ecclesiological-ethical" implications according to the 1559 Institutes. Already in the opening paragraphs of Book 4, when he discusses the church as communion of saints, Calvin underlines the unity in fellowship and the need to share their blessings in mutual love. According to the reformed scholar Peter Opitz, the central notion behind Calvin's views of the church polity and practical order, concentrated around the Lord's Supper, is the motif of reconciliation,

Janse, 2008a:396-397:

[D]e blikrichting (is) tegengesteld. In een onmiskenbare spiritualisering treedt het gavekarakter van het Avondmaal geregeld achter zijn ecclesiologisch-ethische aspecten terug ... De meerwaarde van het sacramentele eten bestaat in de aansporing tot naastenliefde. $\mathrm{Er}$ is sprake van rationalisering en een sterke accentuering van de ethische condities en implicaties van de communie; het geloof wordt daarbij meer en meer een menselijke activiteit.

9 Janse (2008b) in fact refers to a fourth phase, namely after 1560 , when new possibilities for rapprochement with the Lutherans in Northern Germany emerged and "Calvin returned to his Luther-friendly tune of the 1540s". Janse (2008a:388) makes these four phases even more explicitly clear. 
and he claims that this is also true of Calvin's social ethics - and he grounds this in Calvin's understanding of the communio sanctorum (Opitz, 2009a). Calvin writes:

Moreover, this article of the Creed relates in some measure to the external Church, that every one of us must maintain brotherly and sisterly concord with all the children of God, give due authority to the Church, and, in short, conduct ourselves as sheep of the flock. And hence, the additional expression, the 'communion of saints'; for this clause must not be overlooked, as it admirably expresses the quality of the Church; just as if it had been said, that saints are united in the fellowship of Christ on this condition, that all the blessings which God bestows upon them are mutually communicated to each other ... For if they are truly persuaded that God is the common Father of them all, and Christ their common head, they cannot but be united together in brotherly and sisterly love, and mutually impart their blessings to each other. (Calvin, 1863:4.1.3; italics - DJS.)

Coming to the discussion of the sacraments, particularly the Lord's Supper 4.17, these "ecclesiological-ethical" emphases remain very clear. By this time, in his "mature" understanding, this aspect is obviously integral to his views, in which the real presence of Christ, the gift character of the Supper, the effective participation in Christ through the Spirit, remains the central and underlying conviction (for his overall views including the character of gift, cf. Mathison, 2002; for a very helpful explanation of the centrality of the celebration for Calvin, cf. Hoek, 2009; for the relationship between sign and reality and the notion of real presence, cf. several essays in Gerrish, 1982; more generally for the reformed view, cf. also Wallace, 1982, Wandel, 2006, even Welker, 2000; for the broader notion of "sacramentality" in Calvin, also with regard to creation and the fullness of life, cf. Brinkman, 1991: esp. 43 ff. and Van Dyk, 2006). Precisely based on this conviction (the Lord communicates his body so that He may become one with us altogether), we are exhorted to charity, peace, concord and unity without division.

The Lord intended it (this is my body, take eat) to be a kind of exhortation, than which no other could urge or animate us more strongly, both to purity and holiness of life, and also to charity, peace, and concord. For the Lord there communicates his body so that He may become altogether one with us, and we with Him. Moreover, since He has only one body of which He makes us all to be partakers, we must necessarily, by this participation, all become one body. This unity is represented by the bread which is exhibited in the sacrament. As it is composed of many 
grains, so mingled together, that one cannot be distinguished from another; so ought our minds to be so cordially united, as not to allow of any dissension or division. (Calvin, 1863:4.17.38; italics - DJS.)

In the strongest possible terms, Calvin draws the implications of this unity with Christ in the Supper for our mutual unity. In fact, because of what happens in the sacrament, we can no longer love Christ without loving our brethren and we can no longer harm our brethren without also harming Christ.

We shall have profited admirably in the sacrament, if the thought shall have been impressed and engraven on our minds, that none of our brethren is hurt, despised, rejected, injured, or in any way offended, without our, at the same time, hurting, despising, and injuring Christ; that we cannot have dissension with our brethren, without at the same time dissenting from Christ; that we cannot love Christ without loving our brethren; that the same care we take of our own body we ought to take of that of our brethren, who are members of our body; that as no part of our body suffers pain without extending to the other parts, so every evil which our brothers and sisters suffer ought to excite our compassion. Wherefore Augustine not inappropriately often terms this sacrament the bond of charity. What stronger stimulus could be employed to excite mutual charity, than when Christ, presenting Himself to us, not only invites us by his example to give and devote ourselves mutually to each other, but inasmuch as He makes Himself common to all, also makes us all to be one in Him. (Calvin, 1863:4.17.38; italics - DJS.)

In harsh, almost cynical words Calvin describes the actions of those believers who celebrate the Supper, feeling that Christ is their life and claiming that they are united with Him, while they show no zeal for charity and live alienated and estranged from their brethren they bear witness against themselves, he says, and they rent and tear Christ's body to pieces.

Moreover, as we see that this sacred bread of the Lord's Supper is spiritual food to the pious worshippers of God, on tasting which they feel that Christ is their life, are disposed to give thanks, and exhorted to mutual love; so, on the other hand, it is converted into the most noxious poison to all whom it does not nourish and confirm in the faith, nor urge to thanksgiving and charity. For people who, without any spark of faith, without any zeal for charity, rush forward like swine to seize the Lord's supper, do not at all discern the Lord's body. For, inasmuch as 
they do not believe that body to be their life, they put every possible affront upon it, stripping it of all its dignity, and profane and contaminate it by so receiving; inasmuch as while alienated and estranged from their brethren, they dare to mingle the sacred symbol of Christ's body with their dissensions. No thanks to them if the body of Christ is not rent and torn to pieces. By this unworthy eating, they bring judgment on themselves. They bear witness against themselves. Being divided and separated by hatred and ill-will from their brethren, that is, from the members of Christ, they have no part in Christ, and yet they declare that the only safety is to communicate with Christ, and be united with Him. (Calvin, 1863:4.17.40; italics DJS.)

This is the reason, he says, why Paul calls the church to examine themselves, whether they indeed seek to regard their brethren as members of their own body as they themselves are regarded by Christ.

For this reason Paul commands everyone to examine themselves before they eat of that bread and drink of that cup. By this, as I understand it, he means that everyone should descend into themselves, and consider ... whether with zeal for purity and holiness they aspire to imitate Christ; whether, after his example, they are prepared to give themselves to their brethren. And to hold themselves in common with those with whom they have Christ in common; whether, as they themselves are regarded by Christ, they in their turn regard all their brethren as members of their own body, or like their members, desire to cherish, defend, and assist them, not that the duties of faith and charity can now be perfected in us, but because it behooves us to contend and seek, with all out heart, daily to increase our faith. (Calvin, 1863:4.17.40; italics - DJS.)

\section{6. "Nothing has caused me greater sorrow": a South African footnote}

Of course, right through his life Calvin was only too aware of the existence of such dissensions and divisions in the church - in spite of the truth about the unity with Christ and with one another. Very often, these divisions were in fact expressed and experienced as divisions around the sacraments, both baptism and the Lord's Supper. Given his convictions about the unity of the church and the nature of the sacraments, he suffered under these divisions. Nothing has caused him greater sorrow, he once wrote from Strasbourg to Geneva, already in 1539 (Vischer, 2000:23). Many scholars use the 
term tragedy when they write about these divisions in the church and also within the protestant movement itself (Durand, 1964a:24; cf. also Berkouwer's chapter "Avondmaal en gemeenschap", 1954: 371-395). It is precisely for this reason - the tragedy and scandal of disunity - that he engaged himself so whole-heartedly in all his ecumenical endeavours, on different fronts over many years (for an interesting and constructive proposal to rethink central issues in the tradition - real presence, sacrifice, ministry - in order to overcome ecumenical differences and also to contribute to social ethics, cf. Hunsinger, 2008).

In South Africa, the many divisions within reformed churches and the many controversies about church unity could also be seen as tragedy and scandal, and it is no wonder that these very words of Calvin regarding the divisions and the lack of a zeal for charity at the Lord's Supper would have such a powerful history of reception in South African churches, particularly since the divisions on the basis of race and social status within the Dutch Reformed Church family tragically had their symbolic beginnings in separation at the table, in 1857 (Pauw, 2007:71-75). A reformed theologian and ecumenical church leader like Allan Boesak would often quote these words from the 1559 Institutes (cf. Boesak, 1984:107).

It is, of course, also possible to argue that tragic dissensions and divisions regarding gender are allowed to exist in the church, including many churches in Calvin's legacy, and particularly around the table of the Lord's Supper, for example in the words of the reformed feminist theologian Leanne van Dyk (2006:218-219):

\begin{abstract}
Ambiguity clusters around the wonderful Calvinian theme of feasting at the table of God's hospitality in the Lord's Supper. The Lord's Table has long been undermined by the exclusion of women as ordained clergy. There are still many Protestant denominations with roots in the Reformed tradition that continue to restrict ordained ministry to men. The argument over women's ordination has tended to focus on the interpretation of a few Pauline texts and on essentialist understandings of both women and men. A distinctly Reformed feminist approach might illuminate the issue of women's ordination in a new way by stressing the implications of a Reformed sacramental theology for hospitality at the table.
\end{abstract}

Of course, it is important to distinguish between Calvin's own views, the history-of-reception of his views, and the contemporary relevance of his views (Billings, 2009a). Leaving aside the history-ofreception and any possible contemporary relevance, it is hard not to 
feel something of the sorrow that Calvin must have experienced as a result of the tension between his views regarding the unity of the church received as gift in the real unity with Christ and, therefore, with one another in the sacrament of the table on the one hand and the tragedy of the divisions in the church of his time - in spite of his own ecumenical passion and all his commitment to serve this unity, koinonia, peace and mutual charity.

With regard to the history-of-reception and the contemporary relevance, it is still appropriate to end with the words with which Durand concluded almost fifty years ago.

Die ekumeniese worsteling van die Gereformeerde vaders was daarop gerig om hul belydenis van die gegewe eenheid van die kerk in Christus sigbaar tot openbaring te bring. Hierin het hulle ons voorgegaan. Indien ons sou wou berus in die toestand van 'n verskeurde kerk, of ons sou wou tevrede stel met die gedagte dat daar darem tog die onsigbare eenheid is, of, erger nog, indien ons die toestand van gebroke eenheid prinsipieel sou wou regverdig, sal ons nie alleen ontrou wees aan die geestelike erfenis van ons 'vaders' nie, maar ten diepste aan Christus self, in Wie die eenheid reeds 'n werklikheid is. Die indikatief, die vanselfsprekendheid waarmee die Nuwe Testament praat van die eenheid in Christus, roep as vanself die imperatief, die bevel tot die bewaring van hierdie eenheid, op. Daarom, wanneer in die gemeente van Korinthe die eenheid bedreig word deur sondige partyskappe, klink die vraag: 'Is Christus verdeel?' (1 Kor. 1:13) - 'n vraag wat nie alleen maar 'n verbod inhou nie, maar die sinloosheid van die toestand aandui. (Durand, 1964a:39; italics - JJFD.)

\section{List of references}

BAARD, R.S. (forthcoming). Sexism and sin-talk: toward a feminist constructive doctrine of sin. Louisville: Westminster John Knox.

BEINTKER, M. 2009. Calvins theologisches Denken als ökumenische Herausforderung. (In Weinrich, M. \& Möller, U., Hrsg. Calvin Heute: Impulse der reformierten Theologie für die Zukunft der Kirche. NeukircherVluyn: Neukirchener Verlag. S. 151-169.)

BERKOUWER, G.C. 1954. De sacramenten. Kampen: Kok.

BERKOUWER, G.C. 1970. De kerk. Vol. 1: Eenheid en katholiciteit. Kampen: Kok.

BEST, T.F. \& GASSMANN, G. 1994. On the way to fuller koinonia. Geneva: World Council of Churches.

BILLINGS, J. 2007. Calvin, participiation, and the gift: the activity of believers in union with Christ. Oxford: Oxford University Press. 
BILLINGS, J. 2009a. John Calvin and the sacraments: a contemporary appraisal. Paper presented at IRTI Conference in Aix-en-Provence celebrating Calvin 500. (Unpublished paper.)

BILLINGS, J. 2009b. To unite us to our God: the Lord's Supper, the law of love, and justice. Stellenbosch. (Unpublished paper.)

BIRMELÉ, A. 2003. Kirchengemeinschaft: ökumenische Fortschritte und methodologische Konsequenzen. Münster: Lit Verlag.

BIRMELÉ, A. 2009. Calvins Kirchenverständnis und die heutigen ökumenischen Herausforderungen. (In Weinrich, M. \& Möller, U., Hrsg. Calvin Heute: Impulse der reformierten Theologie für die Zukunft der Kirche. NeukircherVluyn: Neukirchener Verlag. S. 103-118.)

BLEI, K. 2005. Communion and catholicity: reformed perspectives on ecclesiology. Reformed world, 55(4):369-379.

BOESAK, A.A. 1984. Black and reformed: apartheid, liberation and the Calvinist tradition. Maryknoll: Orbis.

BRINKMAN, M.E. 1991. Schepping en sacrament. Zoetermeer: Meinema.

BRINKMAN, M.E. 2006. Unity: a contribution from the reformed tradition. (In Goheen, M.W. \& O'Gara, M., eds. That the world may believe. Lanham: University Press of America. p. 113-124.)

BRINKMAN M.E. 2007. The church as sacrament. Paper presented at the IRTI Conference, Cluj, Rumania. (Unpublished paper.)

BUSCH, E. 1997. Calvin-Studienausgabe. Band 2: Gestalt und Ordnung der Kirche. Neukirchen-Vluyn: Neukirchener Verlag.

BUSCH, E. 2007. Who was and is Calvin? Interpretations of recent times. Reformed world, 57(4):237-250.

BUTIN, P.W. 1995. Revelation, redemption, and response: Calvin's trinitarian understanding of the divine-human relationship. Oxford: Oxford University Press.

CALVIN, J. 1848. Commentary on the epistles to the Corinthians. Edinburgh: Calvin Translation Society.

CALVIN, J. 1863. Institutes of the Christian religion. Trans. by $\mathrm{H}$. Beveridge. Edinburgh: Clark.

CALVIN, J. 1958. Tracts and treatises. Volumes 1-3. Grand Rapids: Eerdmans.

CALVIN, J. 1980. Letters of John Calvin. Edinburgh: Banner of Truth.

CAMPI, E. 2007. Calvin's understanding of the church. Reformed world, 57(4):290-305.

COMPIER, D H. 2001. Calvin's rhetorical doctrine of sin. Lewiston: Edwin Mellen.

DAVIS, T.J. 1995. The clearest promises of God: the development of Calvin's eucharistic teaching. New York: AMS Studies.

DAVIS, T.J. 2008. This is my body: the presence of Christ in reformation thought. Grand Rapids: Baker.

DE GRUCHY, G.W. 2009. John Calvin. Wellington: Lux Verbi.BM.

DOUGLASS, J.D. 2004. Calvin in ecumenical context. (In McKim, D.K., ed. The Cambridge companion to John Calvin. Cambridge: Cambridge University Press. p. 305-316.)

DOUGLASS, J.D. 2005. Calvin, Calvinism and ecumenism. Reformed world, 55(4):295-310.

DURAND, J.J.F. 1961. Una sancta catholica in sendingperspektief. Amsterdam: Ten Have. 
DURAND, J.J.F. 1964a. Ware ekumenisiteit: die gereformeerde vaders. (In Van Wijk, A.J., red. Die ekumene. Stellenbosch: Kosmo. p. 24-39.)

DURAND, J.J.F. 1964b. Calvyn as ekumeniese gees. Nederduitse Gereformeerde teologiese tydskrif, 5(3):167-182.

DUVENAGE, B. 1977. Calvyn en die ekumeniese roeping van die kerk. Potchefstroom: $\mathrm{PU}$ vir $\mathrm{CHO}$.

FABER, E.-M. 2009. Mutual connectedness as a gift and a task: on John Calvin's understanding of the church. (In Hirzel, M.E. \& Sallmann, M., eds. John Calvin's impact on church and society, 1509-2009. Grand Rapids: Eerdmans. p. 122-144.)

FUCHS, L.F. 2008. Koinonia and the quest for an ecumenical ecclesiology. Grand Rapids: Eerdmans.

GAMBLE, R.C., ed. 1992. Calvin's ecclesiology: sacraments and deacons. New York: Garland.

GEORGE, T. 1990. John Calvin and the church. Louisville: Westminster John Knox.

GERRISH, B.A. 1981. Reformatio perennis. Pittsburgh: Pickwick.

GERRISH, B.A. 1982. The old protestantism and the new. Chicago: University of Chicago Press.

GERRISH, B.A. 1993. Grace and gratitude: the eucharistic theology of John Calvin. Eugene: Wipf \& Stock.

HERON, A. 2002. The relevance of the early reformed tradition, particularly of Calvin, for an ecumenical ecclesiology today. (In The church in reformed perspective. Geneva: John Knox Press. p. 47-74.) (John Knox Series, 13.)

HOEK, J. 2009. Een nooit vervulde hartenwens van Calvijn: elke Zondag avondmaal. (In De Leede, B., Brouwer, R.R. \& Spronk, K. Het calvinistisch ongemak. Kampen: Kok. p. 171-183.)

HUIZING, K. 2009. Calvin. Edition Chrismon. Frankfurt aM.: Hansiches Verlagshaus.

HUNSINGER, G. 2008. The eucharist and ecumenism. Cambridge: Cambridge University Press.

JANSE, W. 2008a. Sacramenten. (In Selderhuis, H.J., red. Calvijn: handboek. Kampen: Kok. p. 387-397.)

JANSE, W. 2008b. Calvin's eucharistic theology: three dogma-historical observations. (In Selderhuis, H.J., ed. Calvinus sacrarum literarum interpres. Göttingen: Vandenhoeck \& Ruprecht. p. 37-69.)

JONES, S. 1995. Calvin and the rhetoric of piety. Louisville: Westminster John Knox.

JONKER, W.D. 1962. Die sendingbepalinge van die Ned. Gereformeerde Kerk van Transvaal. Potchefstroom: Kerk en Wêreld.

JONKER, W.D. 1965. Aandag vir die kerk. Potchefstroom: Die Evangelis.

KOFFEMAN, L.J. 2009. Calvinus oecumenicus? De O-factor van Calvijn. (In De Leede, B., Brouwer, R.R. \& Spronk, K. Het calvinistisch ongemak. Kampen: Kok. p. 186-200.)

LEUENBERG DOCUMENTS 1. 1995. Church of Jesus Christ. Frankfurt: Otto Lembeck.

LINK, C. 2009. Johannes Calvin: Humanist, Reformator. Zürich: Theologischer Verlag Zürich. (Lehrer der Kirche.)

LOCHER, G.W. 2004. Sign of the advent: a study in protestant ecclesiology. Fribourg: Academic Press. 
MATHISON, K.A. 2002. Given for you: reclaiming Calvin's doctrine of the Lord's Supper. Phillipsburg: P\&R Publishing.

NIJENHUIS, W. 1959. Calvijn en de eenheid der kerk in het licht van zijn briefwisseling. 's Gravenhage: Nijhoff.

OPITZ, P. 2009a. Calvins Interpretation der Kirche als "Gemeinschaft der Heiligen" als Herausforderung für Kirche und Gesellschaft. (In Weinrich, M. \& Möller, U., Hrsg. Calvin Heute. Neukircher-Vluyn: Neukirchener Verlag. S. 225-242.)

OPITZ, P. 2009b. Leben und Werk Johannes Calvins. Göttingen: Vandenhoeck \& Ruprecht.

PARTEE, C. 2008. The theology of John Calvin. Louisville: Westminster John Knox.

PAUW, J.C. 2007. Anti-apartheid theology in the Dutch Reformed family of churches. Amsterdam: Vrije Universiteit. (Ph.D. thesis.)

PLASGER, G. 2008a. Ecclesiologie. (In Selderhuis, H.J., red. Calvyn handboek. Kampen: Kok. p. 365-373.)

PLASGER, G. 2008b. Johannes Calvins Theologie: eine Einführung. Göttingen: Vandenhoeck \& Ruprecht.

RETIEF, G.J. 1984. Die verhouding tussen mortificatio en vivificatio in die leer van die heiliging by Johannes Calvyn. Stellenbosch. (Ongepubliseerde doktorale verhandeling.)

RIGGS, J.W. 2002. Baptism in the reformed tradition: an historical and practical theology. Louisville: Westminster John Knox.

SCHMIDT, U., Hrsg. 1972. Johannes Calvin und die Kirche. Stuttgart: Evangelisches Verlagswerk.

SMALL, J.D. 2006. What is communion and when is it full? Reformed world, 56(2):154-169.

SMIT, D.J. 2009. En ook gehoor? Vrae rondom die gereformeerde siening van die kerk. Nederduitse Gereformeerde teologiese tydskrif, 50(1 \& 2):198211.

SPIERLING. K.E. 2005. Infant baptism in reformation Geneva: the shaping of a community, 1536-1564. Louisville: Westminster John Knox.

STROHM, C. 2009. Johannes Calvin: Leben und Werk des Reformators. München: Beck.

TAMBURELLO, D.E. 1994. Union with Christ: John Calvin and the mysticism of St. Bernard. Louisville: Westminster John Knox.

TYLENDA, J.N. 1981. The ecumenical intention of Calvin's early Eucharistic teaching. (In Gerrish, B.A. Reformation perennis. Pittsburgh: Pickwick. p. 27-47.)

VAN DE BEEK, A. 2002. The dis-unity of the reformed church. (In The church in reformed perspective. Geneva: John Knox Press. p. 109-134.) (John Knox Series, 13.)

VAN DYK, L. 2006. The gifts of God for the people of God. (In Pauw, A.P. \& Jones, S., eds. Feminist and womanist essays in reformed dogmatics. Louisville: Westminster John Knox. p. 204-220.)

VAN GENDEREN, J. 1983. De doop bij Calvijn. (In Van 't Spijker, W., Balke, W., Exalto, K. \& Van Driel, L., reds. Rondom de doopvont. Kampen: De Groot Goudriaan.

VAN 'T SPIJKER, W. 2001. Calvin: Biographie und Theologie. Göttingen: Vandenhoeck \& Ruprecht. 
VISCHER, L. 2000. Pia conspiratio: Calvin on the unity of Christ's church. Geneva: John Knox Center.

VISCHER, L. 2002. The church and being the church in reformed perspective. (In The church in Reformed perspective. Geneva: John Knox Press. p. 3146.) (John Knox Series, 13.)

WALLACE, R.S. 1982. Calvin's doctrine of Word and sacrament. Eugene: Wipf \& Stock.

WANDEL, L.P. 2006. The eucharist in the reformation: incarnation and liturgy. Cambridge: Cambridge University Press.

WARC

see WORLD ALLIANCE OF REFORMED CHURCHES

WELKER, M. 2000. What happens in holy communion? Grand Rapids: Eerdmans.

WORLD ALLIANCE OF REFORMED CHURCHES. 2008. Legacy of John Calvin. Geneva.

ZACHMANN, R.C. 2008. Communio cum Christo. (In Selderhuis, H.J., red. Calvijn: handboek. Kampen: Kok. p. 409-417.)

\section{Key concepts:}

Calvin

church unity

Lord's Supper

sacraments

Kernbegrippe:

Calvyn

kerkeenheid

Nagmaal

sakramente 
